\title{
Wind effect as forcing factor controlling distribution and diversity of copepods in a shallow temperate estuary (Solis Grande, Uruguay)*
}

\author{
M. GÓMEZ-ERACHE, W. NORBIS, and D. BASTRERI \\ Instituto de Biología, Sección Oceanografía, Facultad de Ciencias, Iguá 4225, Montevideo. \\ Fax: (005-982) 525 8617. E-mail: mge@fcien.edu.uy
}

\begin{abstract}
SUMMARY: Spatial and temporal variations of planktonic copepods were investigated in relation to environmental conditions in the Solís Grande estuary $\left(34^{\circ} 22^{\prime} \mathrm{S}, 55^{\circ} 33^{\prime} \mathrm{W}\right)$, Uruguay. Over a period of fifteen days, samples were taken daily at three stations along the main axis of the estuary, and the species composition and abundance were determined. The Solís Grande is a shallow estuary $(2.0 \mathrm{~m})$ with no vertical discontinuities. Comparisons of surface versus bottom hydrographic values indicated no vertical stratification of temperature and salinity during the studied period. The species-environmental relationships explain $63.6 \%$ of the system's variability considering the two first axes from Redundance Analysis (RA). Copepods showed strong differences in distribution and abundance between stations and successive days. In the region the winds quickly rotate from sectors S-SE (frontal period) to E-NE (post-frontal period). Changes in abundance were significantly related to the inflow and outflow of water produced by the rotation of winds. At smaller space and time scales, the differences highlighted by the RA were the result of wind-forced hydrodynamics after the frontal period. In this situation hydrographic features were dominant (factor one of RA) and wind effects were of secondary importance (factor two of RA). Six species were identified and the estuary was clearly dominated by Acartia tonsa. The results showed two negatively correlated groups: one was integrated by Oithona nana, O. simplex, Paracalanus parvus and $P$. crassirostris while the second group was integrated by A. tonsa and Euterpina acutifrons. Environmental variability may be responsible for the low diversity.
\end{abstract}

Key words: zooplankton, copepod diversity, environmental factor, wind.

\section{INTRODUCTION}

Temporal changes in the distribution and abundance of zooplankton may be caused by variations of many abiotic and biotic factors. Especially in estuaries the distribution of zooplankton depends largely upon the physical and dynamic characteristics of the water. Relations between plankton and environment in estuarine areas have been studied by several authors, by analyzing the distribution of

\footnotetext{
*Received March 17, 1999. Accepted October 5, 1999.
}

species in relation to horizontal and vertical environmental gradients (Maurer et al., 1978; Collins and Williams, 1982; Stearns et al., 1989; Hough and Naylor, 1991; Madariaga et al., 1992; Laprise and Dodson, 1993, 1994). More recently the effect of wind on fish larvae (Govoni and Pietrafesa, 1994) and on dispersal dynamics of postlarval macrofauna of benthic systems (Commito, 1995) was introduced in models as an explanatory variable.

In the Río de la Plata, meteorological factors (rotation of winds) play an important role in the dynamic of its coastal systems (Balay, 1961; Ottman 
and Urien 1965; Nagy et al., 1987; Norbis, 1995; Guerrero et al., 1997). The effect of the astronomical tides along the coast is minimal. This is due to the dynamics of the estuary, to its shallow depth and mainly to the wind action that hides its effect (Balay, 1961; Ottman and Urien, 1965). At Cassino Beach in Southern Brazil, Odebrecht et al. (1995) gave evidence that the mesoscale variability of chlorophyll $a$ and accumulation of patches is primarily controlled by meteorological factors. In Uruguayan estuaries, the zooplankton has received little attention. Milstein (1983) and Milstein and Juanicó (1985) published results on spatial and temporal distribution of plankton communities in Maldonado Bay. These studies demonstrated that copepods dominate the larger members of the zooplankton, and that variations at different spatial and temporal scales overlap, involving different main factors in each scale.

The aim of this study was to investigate spatial and temporal small-scale variations in planktonic copepods in relation to environmental conditions in the Solís Grande estuary.

\section{MATERIALS AND METHODS}

\section{Sampling area}

The Solís Grande river (Fig. 1) situated in the Department of Canelones about $80 \mathrm{~km}$ off Montevideo (34⒉' $\mathrm{S}, 5^{\circ} 33^{\prime}$ ' W, Uruguay), is the second largest estuary on the Uruguayan coast. It covers an area of $1.409 \mathrm{Km}^{2}$ with an average depth of $2.0 \mathrm{~m}$ and a mean annual discharge of $145 \mathrm{~m}^{3} \mathrm{~s}^{-1}$. No data exist on astronomical tides for Solis Grande estuary, but the adjacent area (Río de la Plata) have a small tidal amplitude $(0.3 \mathrm{~m})$ (MTOP-PNUD, 1979; Mazio and Martínez, 1989). The lower estuary has a gentle slope and its communication with the Río de la Plata is permanent, causing an important inward water flow from the latter. The characteristics and rotations of predominant winds (north and south sectors) over the year generate strong upstream coastal water currents from the Río de la Plata (MTOP-PNUD, 1979).

\section{Sampling and field measurements}

Zooplankton and hydrographical data were obtained daily from November 16 to 30, 1982 between 0700 and $0900 \mathrm{~h}$ (local time). Three stations were sampled on a roughly north to south tran-
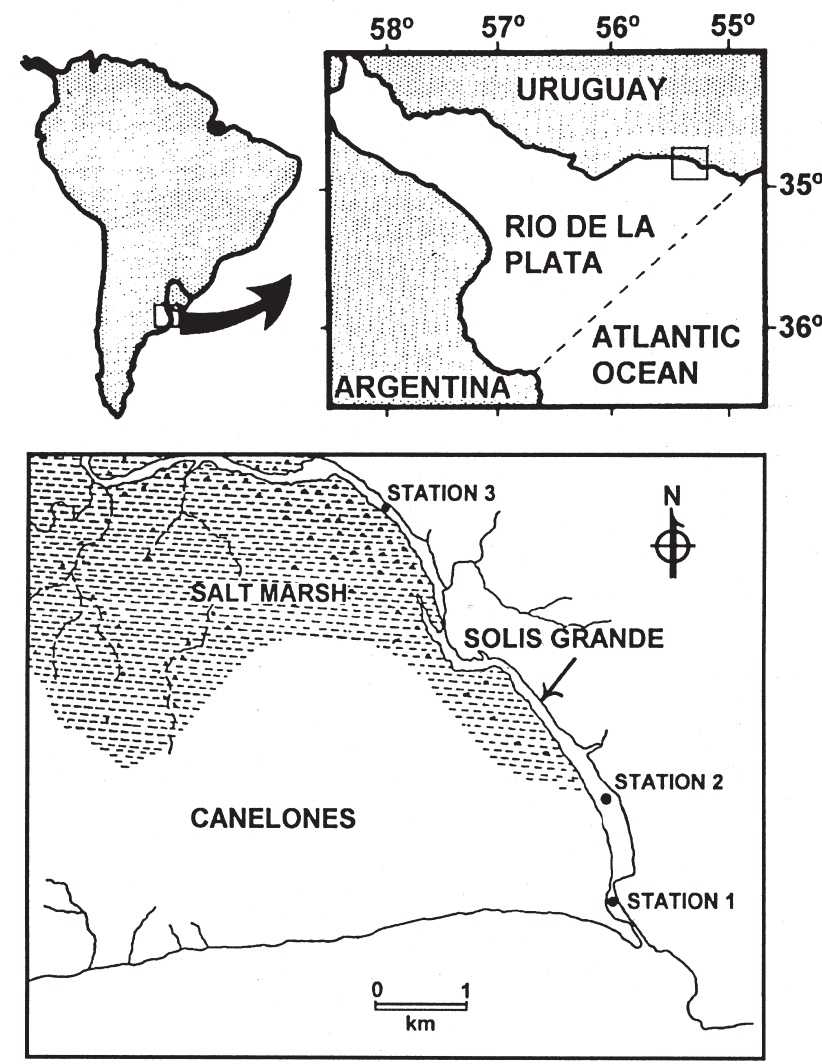

FIG. 1. - Study area and locations of the three stations sampled from November 16 to 30,1982 .

sect across the Solís Grande estuary (Fig.1). The location of the stations was selected to cover the entire salinity gradient from the upstream of Solís Grande to its mouth. Depths at the stations 1,2 and 3 were $2.5 \mathrm{~m}, 1.8 \mathrm{~m}$ and $2.4 \mathrm{~m}$ respectively. Water temperature and salinity were measured (YSI model 33 SCT) at each station at the surface and bottom, and transparency was determined with a Secchi disk. Hourly data of wind direction and speed, were provided by the Oceanographic, Meteorological and Hydrographical Service of the Army (SOHMA, Montevideo) at Laguna del Sauce weather station, situated $40 \mathrm{~km}$ from the study area.

The sampling strategy was oriented to detect zooplankton and environmental variability at a small scale (days). On days 23 and 29, only station 2 was sampled, and at day 27 no samples were taken. The zooplankton samples corresponding to station 3 at day 16 were lost. At each station, zooplankton samples were collected from a standard net $(158 \mu \mathrm{m})$ with a flowmeter fitted in its mouth. Five-minute horizontal tows were carried out at approximately $1 \mathrm{~m} \mathrm{~s}^{-1}$, sampling water of the upper meter of the column ("surface") and of the lower meter ("bottom"). 


\section{Sample treatment and data analysis}

Each sample was first described by the abundance of species of copepods. Samples for counting of species were brought to a constant volume $(100 \mathrm{ml})$ and subsampled with a $10 \mathrm{ml}$ Stempel pipette. At least two aliquots, containing a minimum of 500 zooplankters, were counted using a Wild M5 stereoscopic microscope. The resulting abundances were expressed as the mean number per cubic meter.

In order to describe characteristics and distribution patterns of zooplankton species in the sampling period, the Shannon-Weaver Diversity Index (Shannon and Weaver, 1949) was used. To test differences between species collected in surface and bottom water, the non-parametric MannWhitney test (Sokal and Rohlf, 1981) was applied. Differences between surface and bottom temperature and salinity were tested by Studenttest (Sokal and Rohlf, 1981).

Abundance species data were $\log (\mathrm{x}+1)$ transformed. Two "stations-day-by-variables" matrices (species and environmental) were constructed. Species were classified hierarchically, for cluster analysis choosing the correlation coefficient as a measure of associations (Sokal and Rohlf, 1962) and the unweighted pair group method using arithmetic averages (UPGMA; Sokal and Michener, 1958) as aggregation algorithm. The distortion of the relationships was measured by cophenetic correlation coefficient (Cunningham and Ogilvie, 1972). Relationships between abundance of zooplankton species and environmental variations were analyzed using Redundancy Analysis (RA) (ter Braak, 1987). It is used when responses of the species are expected to be related to their habitat conditions, as is the case in short segments of ecological gradients (Jongman et al., 1987). We used the computer program CANOCO (Canonical Community Ordination) (ter Braak, 1988; 1990) that includes RA. The "stations-day-environmental" matrix was constructed taking into account the following variables: temperature (TEM), salinity (SAL), depth of Sechii disk (SEC), occurrence of calms (C), daily average wind speed (Avs), daily maximum speed (Maxs), and persistence of winds (total number of occurrences per sector during a period of 18 hours: from 0600 to 2400) in sectors north (N), north-east (NE), north-west (NW), south (S), south-west (SW), south-east (SE), east (E) and west (W).

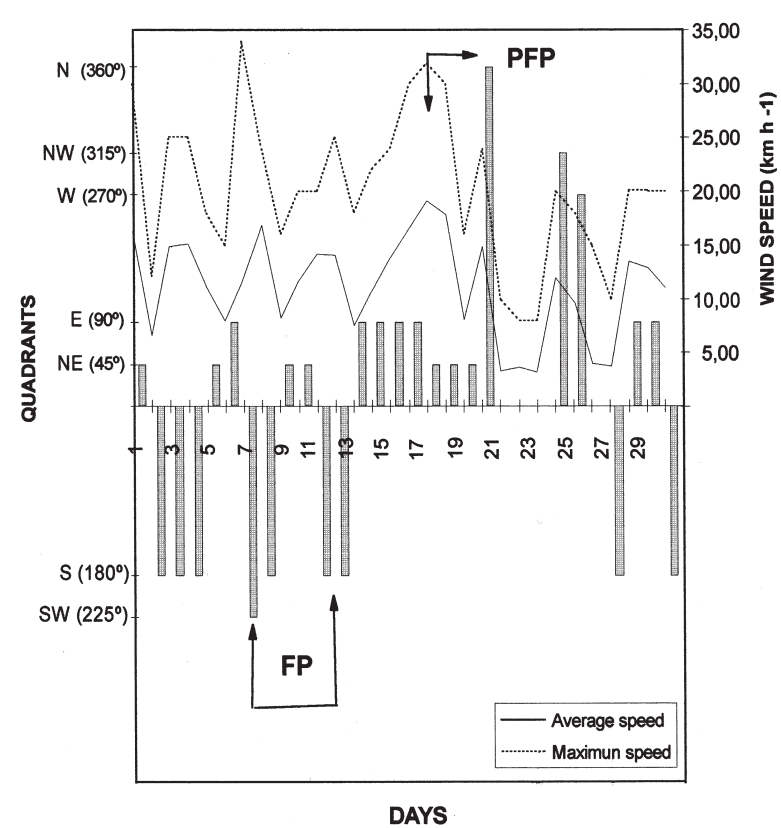

FIG. 2. - Daily average and maximum speed and dominant persistence of winds during November, 1982. The bars indicates the direction of wind; FP: Frontal Period and PFP: Post Frontal Period.

\section{RESULTS}

\section{Environmental variables}

Figure 2 shows that from November 6 to 8, 1982, roughly ten days before the start of our study, the winds blew from the quadrant $\mathrm{E}$ to SW-S reaching velocities up to $34 \mathrm{~km} \mathrm{~h}^{-1}$. Strong $\mathrm{E}$ to NE winds (20$32 \mathrm{Km} \mathrm{h}^{-1}$ ) prevailed during days 14 to 18 , and relatively weak variable winds during days 21 to 23 . Calm periods predominated after the passage of fronts.

There were no significant differences $(p>0.05)$ between temperature and salinity data from surface and bottom samples (Table 1), so average values were used for later analysis. From days 19 to 21 colder and saltier water entering from the Rio de la Plata was registered (Figs. 3a and 3b). Subsequently, salinity declined and temperature increased with a similar trend at the three stations. There was an inversion of the salinity gradient from days 25 to 31 (Fig. 3b).

At the three stations, the water transparency increased in a similar manner during days 18 to 21 , differed during days 22 to 24 and tended to remain stable up to the end of the sampling period (Fig. 3c).

\section{Zooplankton composition}

The mesozooplankton of the Solís Grande estuary was clearly dominated by copepods. No signifi- 
TABLE 1. - Environmental variables registered along the studied period at the 3 stations and results of Student t-test for testing the differences between surface and bottom (STD: standard deviation; ns: $\mathrm{p}>0.05$ ).

\begin{tabular}{|c|c|c|c|c|c|c|c|}
\hline $\begin{array}{l}\text { Environmental } \\
\text { variable }\end{array}$ & Mean & $\begin{array}{l}\text { Surface } \\
\text { STD }\end{array}$ & $\mathrm{N}$ & Mean & $\begin{array}{l}\text { Bottom } \\
\text { STD }\end{array}$ & $\mathrm{N}$ & t-value \\
\hline \multicolumn{8}{|l|}{ Station 1} \\
\hline Temperature & 17.17 & 3.343 & 13 & 15.71 & 3.389 & 13 & $1.106 \mathrm{~ns}$ \\
\hline Salinity & 16.74 & 6.649 & 13 & 18.92 & 7.997 & 13 & $0.757 \mathrm{~ns}$ \\
\hline \multicolumn{8}{|l|}{ Station 2} \\
\hline Temperature & 17.757 & 2.467 & 14 & 16.757 & 2.314 & 14 & $1.105 \mathrm{~ns}$ \\
\hline Salinity & 15.771 & 5.335 & 14 & 16.455 & 5.285 & 14 & $0.382 \mathrm{~ns}$ \\
\hline \multicolumn{8}{|l|}{ Station 3} \\
\hline Temperature & 19.031 & 2.7376 & 13 & 17.931 & 2.785 & 13 & $1.105 \mathrm{~ns}$ \\
\hline Salinity & 13.001 & 5.7853 & 13 & 13.301 & 5.617 & 13 & $0.134 \mathrm{~ns}$ \\
\hline
\end{tabular}
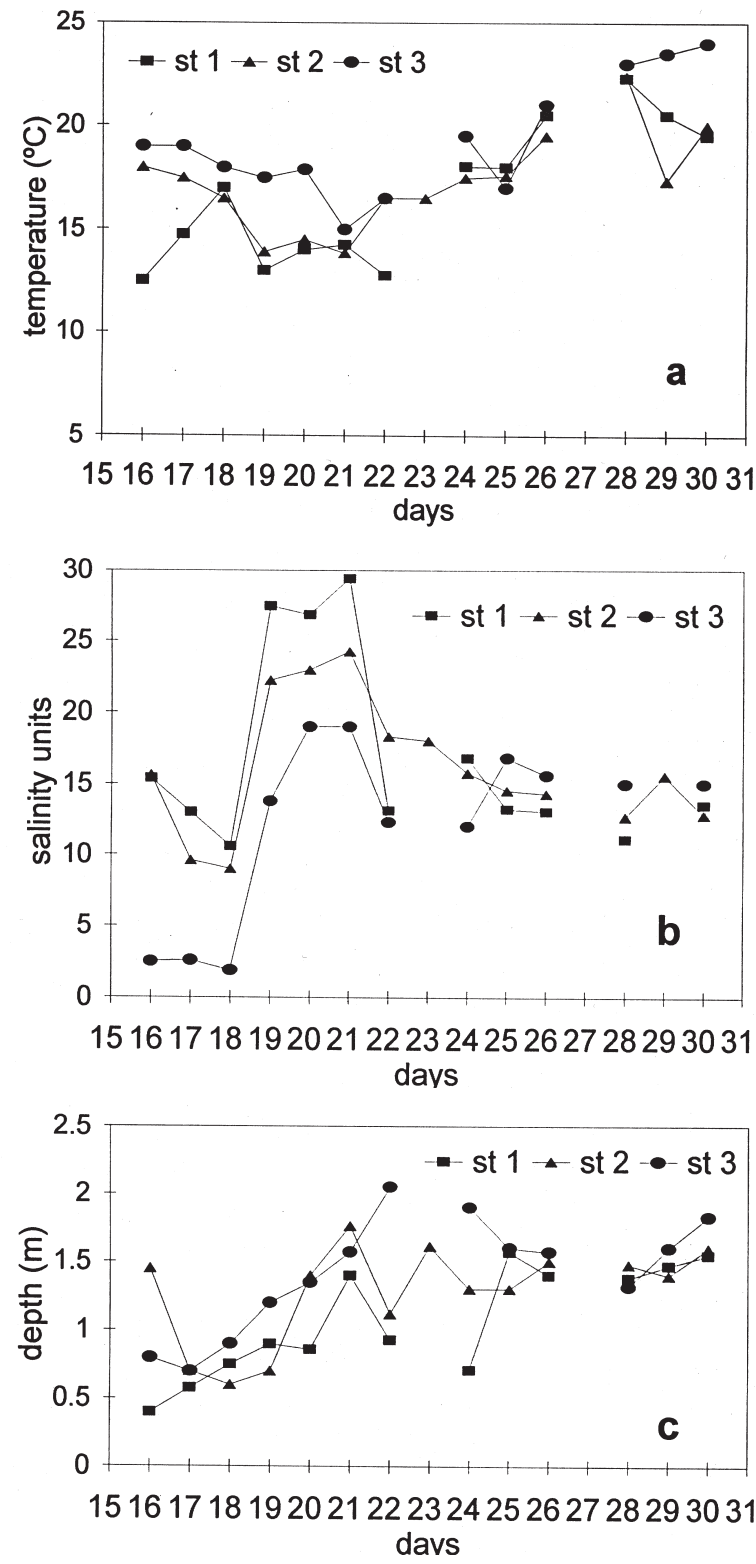

FIG. 3. - Variation of temperature (a), salinity (b) and water transparency (c) during the study period at the three sampling stations.
TABLE 2. - Results for species Mann-Whitney test (MW) for testing the differences between surface and bottom sampling (in all cases $\mathrm{p}>0.05)$.

\begin{tabular}{lcc}
\hline Species & MW test & Sig. level \\
\hline Acartia tonsa & 0.0024 & 0.9604 \\
Paracalanus parvus & 1.1115 & 0.2918 \\
Parvocalanus crassirostris & 3.9878 & 0.0658 \\
Oithona nana & 1.5702 & 0.2102 \\
Oithona simplex & 1.3611 & 0.2433 \\
Euterpina acutifrons & 2.1005 & 0.1472 \\
\hline
\end{tabular}

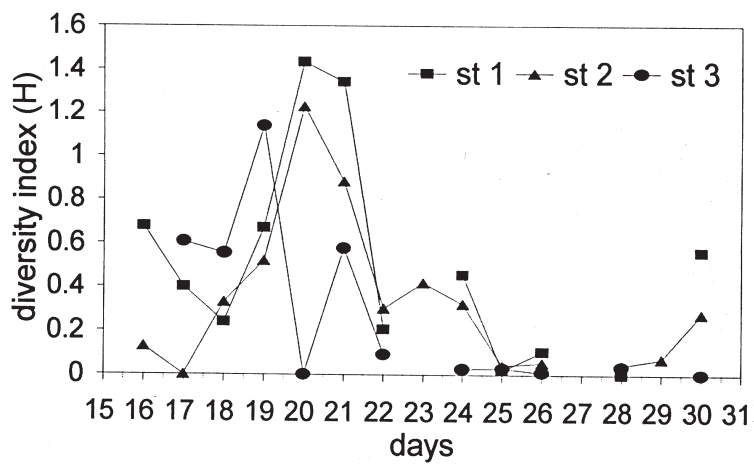

FIG. 4. - Changes of the diversity $\mathrm{H}$ by sampling stations.

cant differences of composition ( $>0.05)$ were registered between surface and bottom samples (Table 2). Six species were identified, and Acartia tonsa was the dominant species throughout the sampling period and at the three stations analyzed (Tabla 3).

At the three sampling stations, the species diversity increased on day 19 , decreased on day 21 , and the values were relatively stable from day 22 until the end of the sampling period (Fig. 4).

Cluster analysis (Fig. 5) showed two groups negatively correlated $(\mathrm{r}=-0.10)$, of which one group included Oithona nana, Oithona simplex, Paracalanus parvus and Parvocalanus crassirostris 
TABLE 3. - Species (\%) and total copepod abundance $\left(\mathrm{N} \mathrm{m}^{-3}\right)$ by station along the sampling period in the Solis Grande river (Aton $=$ Acartia tonsa, Ppar $=$ Paracalanus parvus, Pcra $=$ Parvocalanus crassirostris, Onan = Oithona nana, Osim = Oithona simplex, Eacu = Euterpina acutifrons).

\begin{tabular}{|c|c|c|c|c|c|c|c|}
\hline Station & Day & Aton & Ppar & Pcra & Onan & Osim & Eacu \\
\hline 1 & 16 & 389 & 9 & 9 & 69 & 9 & 0 \\
\hline 1 & 17 & 224 & 2 & 2 & 25 & 2 & 0 \\
\hline 1 & 18 & 129 & 0 & 0 & 9 & 0 & 0 \\
\hline 1 & 19 & 89 & 0 & 59 & 0 & 0 & 0 \\
\hline 1 & 20 & 156 & 8 & 166 & 137 & 143 & 0 \\
\hline 1 & 21 & 4 & 23 & 46 & 74 & 18 & 0 \\
\hline 1 & 22 & 1305 & 3 & 19 & 34 & 0 & 0 \\
\hline 1 & 23 & & & & & & \\
\hline 1 & 24 & 1791 & 9 & 132 & 84 & 2 & 2 \\
\hline 1 & 25 & 1103 & 0 & 3 & 0 & 0 & 0 \\
\hline 1 & 26 & 3864 & 13 & 59 & 0 & 0 & 2 \\
\hline 1 & 27 & & & & & & \\
\hline 1 & 28 & 1509 & 0 & 0 & 0 & 0 & 0 \\
\hline 1 & 29 & & & & & & \\
\hline \multirow[b]{3}{*}{ perc } & 30 & 1203 & 35 & 3 & 176 & 16 & 0 \\
\hline & total & 11767 & 103 & 499 & 607 & 190 & 4 \\
\hline & ntage & 89.34 & 0.78 & 3.79 & 4.61 & 1.44 & 0.03 \\
\hline 2 & 16 & 4591 & 3 & 71 & 6 & 27 & 0 \\
\hline 2 & 17 & 681 & 0 & 0 & 0 & 0 & 0 \\
\hline 2 & 18 & 211 & 0 & 9 & 9 & 0 & 0 \\
\hline 2 & 19 & 484 & 0 & 41 & 36 & 0 & 2 \\
\hline 2 & 20 & 95 & 16 & 17 & 13 & 10 & 2 \\
\hline 2 & 21 & 6 & 0 & 83 & 72 & 2 & 0 \\
\hline 2 & 22 & 847 & 0 & 44 & 21 & 0 & 0 \\
\hline 2 & 23 & 1096 & 0 & 105 & 31 & 0 & 2 \\
\hline 2 & 24 & 3980 & 0 & 299 & 59 & 0 & 0 \\
\hline 2 & 25 & 5242 & 4 & 13 & 13 & 0 & 0 \\
\hline 2 & 26 & 12136 & 0 & 104 & 9 & 0 & 0 \\
\hline 2 & 27 & & & & & & \\
\hline 2 & 28 & 10907 & 2 & 45 & 0 & 0 & 23 \\
\hline 2 & 29 & 5089 & 3 & 13 & 44 & 0 & 0 \\
\hline 2 & 30 & 4202 & 13 & 9 & 248 & 16 & 2 \\
\hline \multirow{2}{*}{\multicolumn{2}{|c|}{$\begin{array}{r}\text { total } \\
\text { percentage }\end{array}$}} & 49571 & 43 & 853 & 563 & 56 & 32 \\
\hline & & 96.97 & 0.08 & 1.67 & 1.10 & 0.11 & 0.06 \\
\hline 3 & 16 & & & & & & \\
\hline 3 & 17 & 119 & 9 & 0 & 19 & 0 & 0 \\
\hline 3 & 18 & 59 & 0 & 0 & 19 & 0 & 0 \\
\hline 3 & 19 & 349 & 9 & 89 & 49 & 29 & 19 \\
\hline 3 & 20 & 9 & 0 & 0 & 0 & 0 & 0 \\
\hline 3 & 21 & 1079 & 0 & 59 & 49 & 79 & 0 \\
\hline 3 & 22 & 2039 & 0 & 0 & 39 & 0 & 0 \\
\hline 3 & 23 & & & & & & \\
\hline 3 & 24 & 2199 & 0 & 0 & 0 & 9 & 0 \\
\hline 3 & 25 & 23079 & 9 & 79 & 9 & 0 & 0 \\
\hline 3 & 26 & 19549 & 0 & 29 & 0 & 0 & 0 \\
\hline 3 & 27 & & & & & & \\
\hline 3 & 28 & 16749 & 0 & 0 & 0 & 0 & 99 \\
\hline 3 & 29 & & & & & & \\
\hline \multirow[b]{3}{*}{ perc } & 30 & 2479 & 0 & 0 & 0 & 0 & 0 \\
\hline & total & 67709 & 27 & 256 & 184 & 117 & 118 \\
\hline & ntage & 98.97 & 0.04 & 0.37 & 0.27 & 0.17 & 0.17 \\
\hline
\end{tabular}

while the second group included Acartia tonsa and Euterpina acutifrons.

Table 4 gives the correlations matrix of RA for the 14 environmental variables, the three species axes and the three environmental axes. The correlation between the first species axis and the first envi-

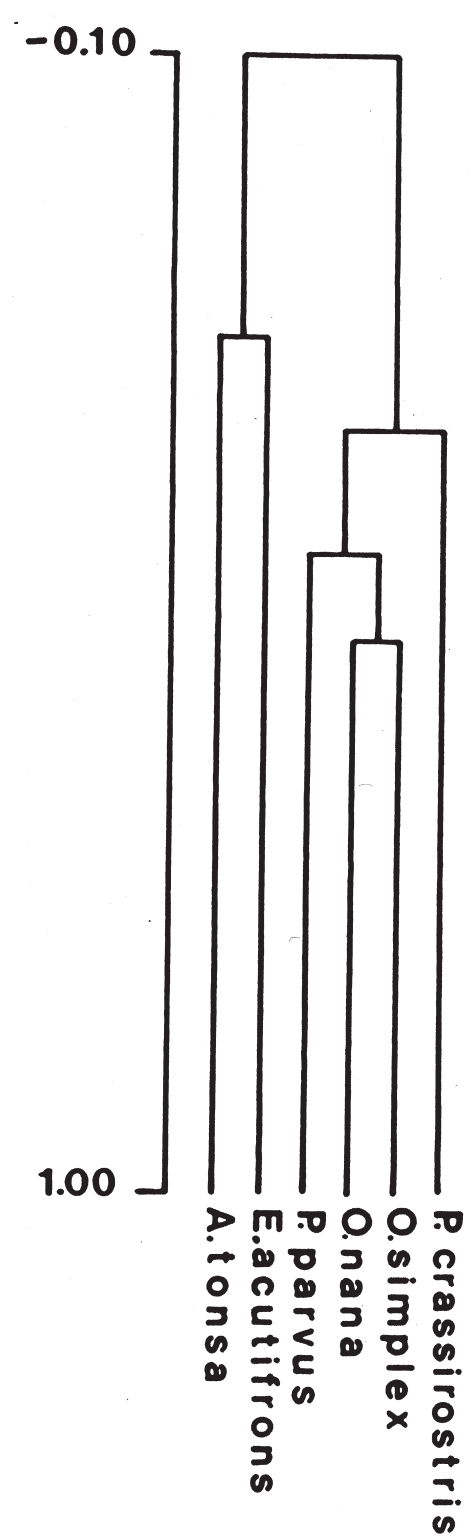

FIG. 5. - Classification of species according to cluster analysis. Ordinate shows coefficient of correlation. Cophenetic correlation coefficient: 0.88 .

ronmental axis was 0.85 and the correlation between the second axis was 0.71 . The eigenvalues and their cumulative percentage for ordination axes indicate that the first two axes represent $63.6 \%$. In the following, results and discussion therefore relate to axes 1 and 2 .

The species-environment biplot ordination (Fig. 6) displays the results for the fourteen environmental variables and the six species, without showing stations days samplings. The first axis separates $A$. tonsa and E. acutifrons from the rest of species. Positive scores on axis 1 were associated with maximum temperature, northern winds and east winds. 
TABLE 4. - Correlation coefficients among environmental variables, species axes and environmental axes, and ordination results estimated by redundancy analysis.

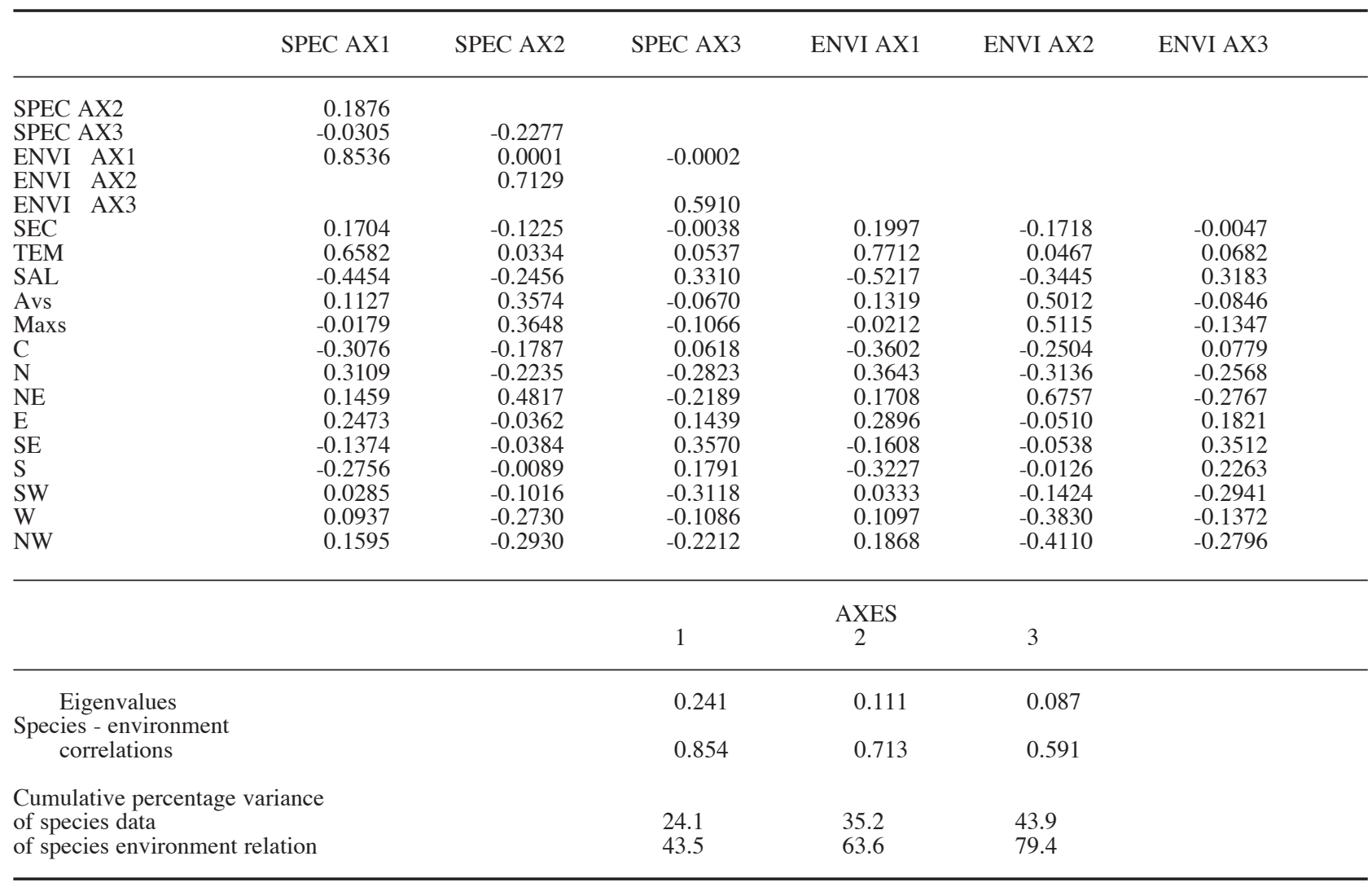

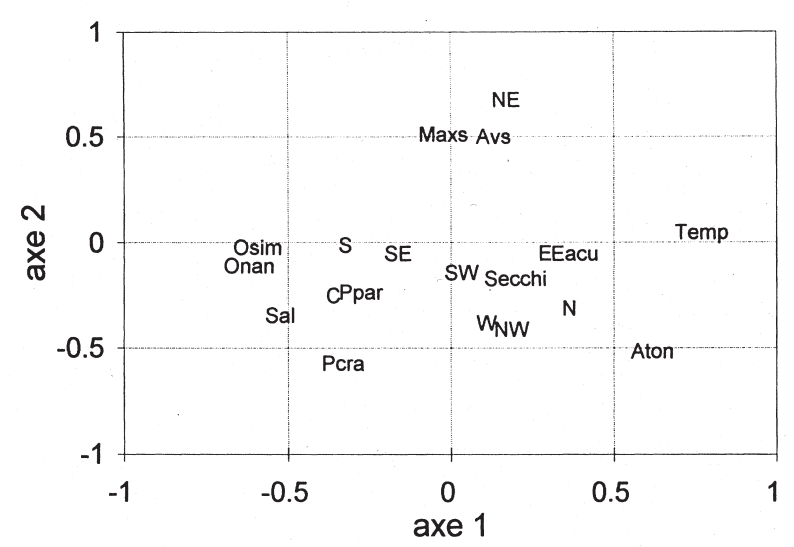

FIG. 6. - Ordination results from RA of copepods species and environmental conditions. The environmental variables are: temperature (TEM), salinity (SAL), depth of Sechii disk (SEC), occurrence of calms (C), daily average speed (Avs) and daily maximum speed (Maxs), and persistence of winds in sectors north $(\mathrm{N})$, north-east (NE), north-west (NW), south (S), south-west (SW), south-east $(\mathrm{SE})$, east $(\mathrm{E})$, and west $(\mathrm{W})$. The species represented are: $O$. simplex (Osim), O. nana (Onan), P. parvus (Ppar), P. crassirostris (Pcra), E. acutiforns (Eacu), and A. tonsa (Aton).

Negative scores on axis 1 were associated with higher salinities, south winds and calms. Positive scores on axis 2 were associated with NE winds and with maximum and mean velocity. Negative scores were associated with NW winds and W winds (Table 4).

\section{DISCUSSION}

Results of this study show that the topography of the estuary, the orientation of its mouth, and the rotation and speed of winds is responsible for inflow and outflow of coastal marine water which in turn determines changes in the distribution and abundance of copepods. Wind stress generally causes vertical mixing and results in the sinking of the mixed upper layer (Farmer, 1972; Denman and Powell, 1984). In various shallow estuaries, Geyer (1997) demonstrated the influence of wind forcing on the salinity structure and flushing characteristics. The Solís Grande, a shallow estuary with no vertical discontinuities, can be considered the vertically mixed type (Pickard and Emery, 1990) during this situation. Its shallow depth and the effects of winds are responsible for strong vertical mixing and inflow and outflow of coastal marine water. The inversion of the salinity gradient between days 25 and 30 could be a consequence of the dynamic of the Río de la Plata. The Solís Grande estuary flows into the fluviomarine zone of the Río de la Plata, and there is frequent fluvial discharge along the Uruguayan 
coast (Lopez and Nagy, 1999; Framiñan et al., 1999). Thus stations 1 and 2, close to the mouth, could receive the influence of fluvial discharge. The decrease of the Río de la Plata northern coast salinity was a consequence of extraordinary increase in fluvial discharge (Nagy et al, 1997), and the influence of wind direction from days 25-26 (NW-W) to day $28(\mathrm{~S})$.

Environmental variability is the principal factor influencing distribution and low diversity in the Solís Grande estuary. In the Río de la Plata region, winds rotate quickly from sectors S-SE to E-NE and the weather tends to be stable. The cycles have a duration that may vary between one and fifty days (Balay, 1961; MTOP-PNUD, 1979). Between days 7 and 18, an atmospheric front originated from the South (frontal period, Balay. 1961) caused a rotation of winds from $\mathrm{S}$ to E-NE and the maximum velocity of wind increased from 20 to $32 \mathrm{~km} \mathrm{~h}^{-1}$. Days with rotation and persistence wind from the E$\mathrm{NE}$ and high velocity (post-frontal period; Balay, 1961) generated strong inflow of colder and saltier water from Río de la Plata. This phenomenon produced an increase in species diversity and is the principal mechanism of transport for zooplankton species, playing a significant role in controlling community dynamics. Towards the end of the sampling period, when velocity and rotation of winds were variable and calm periods prevailed, salinity decreased while temperature increased. At the Uruguayan coast, it is common to find calm situations associated with winds blowing daily from $\mathrm{S}$ to $\mathrm{N}$ during day and from $\mathrm{N}$ to $\mathrm{S}$ during night. This produced a decrease in diversity together with an increase of dominance of $A$. tonsa. At smaller space and time scales, the differences highlighted by the RA were the result of wind-forced hydrodynamics after the frontal period. In this situation hydrographic features have been dominant (factor one of RA) and wind effects have had secondary importance (factor two of RA).

Various authors discuss the use of diversity indices to characterize the community (Wolda, 1981; Magurran, 1988; Washington, 1984). According to Peet (1974), the Shannon index is more sensitive to changes of rare species in community samples. Therefore, the Shannon index could reflect changes in species composition of a determined station when the move of saline water into the estuary was provoked by the rotation of winds.

Plankton species assemblages are not simply the result of the salinity or temperature tolerance of the organisms. Two distinct associations of zooplankton species were detected at the Solís Grande estuary: (1) One group, composed of $P$. parvus, P. crassirostris, $O$. nana and $O$. simplex, was associated with the inflow of Río de la Plata coastal waters (saline waters). These are subtropical species common in coastal waters with marine influence (Björnberg, 1963; Ramírez, 1977). Their entry into the Solís Grande was produced after the post-frontal period led to an increase in diversity. (2) The second group, composed of A. tonsa and E. acutifrons, could be associated with lower salinity and higher temperature. A. tonsa, which is generally related to coastal waters (Björnberg, 1963; Ramírez, 1981; Montú, 1980), was the most abundant species throughout the study period. Its abundance showed a clear downward trend upon entering saltier water and an upward trend towards the end of the sampling period (Bastreri, 1991). In the summer, $A$. tonsa usually dominates in estuarine zooplankton and warm to temperate coastal areas (Uye and Fleminger, 1976). Contrastingly, E. acutifrons can be defined as a rare species with a wide distribution range. It is particularly common in neritic and estuarine waters, tolerating sudden decreases of salinity (Björnberg, 1963; González and Bowman, 1965; Ramírez, 1981, Viñas and Gaudy 1996). Considering an annual sampling strategy, seasonal changes in species composition and abundance could be due to changes in thermal preference for the resident species (Kimmerer, 1993). In our study, the alteration in abundance and diversity, related to changes in salinity and temperature, was forced by influence of external factors. The applied sampling strategy produced information about variations at small temporal and spatial scales, and proved to be useful for studying zooplankton assemblages particularly in this fluctuating environment. According to Milstein and Juanicó (1985), fluctuations at reduced spatial and temporal scales can be equal or of greater magnitude than at large scales, and thus constitute important indicators of the characteristics of the system. The employed sampling strategy unveiled phenomena that had not been perceived at a larger temporary scale. Changes of abundance and composition at a determined station as a function of time reflect the position and mixing of coastal and estuarine water bodies, as we show associating species composition to temperature and salinity. Whether the movements of the estuarine water bodies inside and outside the estuary affect the populations (retention, losses, etc.) can only be checked by following 
the evolution in time of the population in the same estuarine water body. Along the Uruguayan coast, temperature and salinity combined with wind-driven currents potentially provide transport mechanisms, helping zooplankton and other species to reach new habitats for development.

\section{ACKNOWLEDGEMENTS}

W. Norbis was supported by a contract from CSIC (Comisión Sectorial de Investigaciones Científicas-Universidad de la República, Uruguay) during his work in Sec. Ecología funcional, Facultad de Ciencias. The authors express their sincere gratitude to P. Meneses for their cooperation and to Dra. Eva Danulat and Dr. O. Defeo (UNDECIMAR, Fac. de Ciencias, Uruguay). We are grateful to anonymus referees for their constructive criticism of the manuscript.

\section{REFERENCES}

Balay, M. - 1961. El Río de la Plata entre la atmósfera y el mar. Servicio de Hidrografía Naval, H621, Buenos Aires.

Bastreri, D. - 1991. Distribución de los copépodos planctónicos en el estuario del arroyo Solís Grande. Análisis en Componentes Principales. Tésis de Licenciatura en Oceanografía Biológica, Fac. de Ciencias, Uruguay $154 \mathrm{p}$.

Björberng, T.K.S. - 1963. On the marine free-living copepods off Brazil. Bol. Inst. Oceanogr., Sao Paulo, 13: 3-142.

Collins, N.R. and R. Williams. - 1982. Zooplankton of the Bristol Channel and Severn Estuary. The distribution of four copepods in relation to salinity. Mar. Biol., 64: 273-283.

Commito, J.A. - 1995. Dispersal dynamics in a wind-driven benthic system. Limnol. Oceanogr., 40(8): 1513-1518.

Cunningham, K.M. and J.C. Ogilvie. - 1972. Evaluation of hierarchical grouping techniques: a preliminary study. Comp. Jour. 15: 209-213.

Denman, K.L. and T.M. Powell. - 1984. Effects of physical processes on planktonic ecosystems in the coastal ocean. Oceanogr. Mar. Biol., Ann. Rev. 22: 125-168.

Farmer, D.M. - 1972. The influence of wind on the surface waters of Alberni Inlet. PhD Thesis, University of British Columbia, Vancouver, $92 \mathrm{p}$.

Framiñan, M.B., M.P. Etala, E.M. Acha, R.A. Guerrero, C.A. Lasta and O.B. Brown - 1999. Physical characteristics and processes of the Río de la Plata estuary. In: G. M. E. Perillo, M. C. Piccolo and M. Pino-Quivira (Eds.), Estuaries of South America, pp.161-194. Springer-Verlag, Berlin.

Geyer, W.R. - 1997. Influence of wind on dynamics and flushing of shallow estuaries. Estuar. Coast. Shelf Sci., 44: 713-722.

González, J.G. and T.E. Bowman. - 1965. Planktonic copepods from bahía fosforescente, Puerto Rico, and adjacent waters. Proceedings of the United StatesNational Museum, Smithsonian Institute, Washington 117(3513): 241-303.

Govoni, J.J. and L.J. Pietrafesa. - 1994. Eulerian views of layered water currents, vertical distribution of some larval fishes, and inferred advective transport over the continental shelf of North Carolina, USA, in winter. Fish. Oceanogr., 3(2): 120-132.

Guerrero, R., E Acha, M. Framiñan and C.Lasta. - 1997. Physical oceanography of the Río de la Plata estuary, Argentina. Cont. Shelf Res., 17(7): 727-742.

Hough, A. R. and E. Naylor. - 1991. Field studies on retention of the planktonic copepod Eurytemora affinis in a mixed estuary.
Mar. Ecol. Prog. Ser., 76: 115-122.

Jongman, R.H., C.J. ter Braak and O.V. van Tongeren. - 1987. Data analysis in community and landscape ecology. PUDOC, Wageningen. $237 \mathrm{pp}$.

Kimmerer, W.J. - 1993. Distribution patterns of zooplankton in Tomales Bay, California. Estuaries, 16(2): 264-272.

Laprise, R. and J.J. Dodson. - 1993. Nature of environmental variability experienced by benthic and pelagic animals in the St. Lawrence Estuary. Mar. Ecol. Prog. Ser., 94:129-139.

Laprise, R. and J.J. Dodson. - 1994. Environmental variability as a factor controlling spatial patterns in distribution and species diversity of zooplankton in the St. Lawrence estuary. Mar. Ecol. Prog. Ser., 107: 67-81.

López, J. and G.J. Nagy. - 1999. Hydrography and sediment transport characteristics of the Río de la Plata: A Review. In: G.M.E. Perillo, M.C. Piccolo and M. Pino-Quivira (Eds.), Estuaries of South America, pp. 133-159. Springer-Verlag, Berling.

Madariaga, I. de, L. González-Azpiri, A.Villate and E. Orive. 1992. Plankton responses to hydrological changes induced by freshets in a shallow mesotidalestuary. Mar. Coast. Shelf Sci., 35: 425-434.

Magurran, A.E. - 1988. Ecological diversity and its measurements. Croom Helm (ed), London.

Maurer, D., L. Walting, R. Lambert and A. Pembroke. - 1978. Seasonal fluctuation of zooplankton populations in lower Delaware Bay. Hydrobiologia 61(2): 149-160.

Mazio C. and C. Martínez. - 1989. Estudio para la evaluación de la contaminación en el Río de la Plata, CARP, SHN-SOHMA. Informe de Avance $422 \mathrm{pp}$.

Milstein, A. - 1983. Principal component analysis of environmental and zooplanktonic relationships in a very variable coastal area. In: Shuval H.I. (ed), Developments in Ecology and Environmental Quality, pp 347-356. Baladan Intern. Science Services, Rehavot, Philadelphia.

Milstein, A. and M. Juanico. - 1985. Zooplankton dynamics in Maldonado Bay (Uruguay). Hydrobiologia 126: 155-164.

Montú, M. - 1980. Zooplnâncton do estuário da Lagoa dos Patos. I. Estrutura y variaçoes temporais y espaciais da comunidade. Atlântica 4: 53-72.

MTOP-PNUD. - 1979. Proyecto sobre Conservación y Mejora de Playas (URU.73007). Informe Final, Ministerio de Transportes y Obras Públicas. UNESCO, Montevideo, Uruguay, 593 pp.

Nagy, G., J. López Laborde and L. Anastasía. - 1987. Caracterización de ambientes del Río de la Plata Exterior (salinidad y turbiedad). Investigación Oceanológica 1(1): 31-56.

Nagy G.J., C.M. Martínez, R.M. Caffera, G. Pedrosa, E.A. Forbes, A.C. Perdomo and J. López. - 1997. Marco hidrológico y climático del Río de la Plata. In: P.G. Wells and G.R. Daborn (Eds.), El Río de la Plata. Una revisión ambiental. Informe de antecedentes del Proyecto Ecoplata, pp. 17-70. Dalhousie University, Halifax, Nova Scotia, Canada.

Norbis, W. - 1995. Influence of wind, behaviour and characteristics of the croaker (Micropogonias furnieri) artisanal fishery in the Río de la Plata (Uruguay). Fish. Res., 22(1): 43-58.

Odebrecht, C., A.Z. Segatto and C.A. Freitas. - 1995. Surf-zone chlorophyll $a$ variability at Cassino Beach, Southern Brazil. Estuar. Coast. Shelf Sci., 41: 81-90.

Ottman, F. and C.M. Urien. - 1965. Le mélange des eaux douces et marines dans le Río de la Plata. Cahiers Oceanographiques XVII(10): 213-234.

Peet, R.H. - 1974. The measurement of species diversity. Annual Rev. Ecol. Syst., 5: 285-307.

Pickard, G. and L.W.J. Emery. - 1990. Descriptive Physical Oceanography. Pergamon Press, New York.

Ramírez, F.C. - 1977. Planktonic indicators of Argentine shelf and adjacent areas. In: Proceedings of the Symposium of Warm Water Zooplankton (UNESCO), pp 65-68. India.

Ramírez, F.C. - 1981. Zooplancton y producción secundaria. Parte I. Distribución y variación estacional de los copépodos. Contr. Inst. Nac. Invest. Des. Pesq., Mar del Plata ,383: 202-212.

Shannon, C.E. and W. Weaver. - 1949. The mathematical theory of communication. University of Illinois Press, Urbana. $140 \mathrm{pp}$.

Sokal, R.R. and C.D. Michener. - 1958. A statistical method for evaluating systematic relationships. Kansas University Science Bulletin 38: 1409-1438.

Sokal, R.R. and F.J. Rohlf. - 1962. The comparison of dendrograms by objective methods. Taxon 11: 33- 40.

Sokal, R.R. and F.J. Rohlf. - 1981. Biometry. 2nd ed. W. M. Free- 
man \& Company, San Francisco. 462 pp.

Stearns, D. E., P.A. Tester and R.L. Walker. - 1989. Diel changes in the egg production rates of Acartia tonsa (Copepoda, Calanoida) and related environmental factors in two estuaries. Mar. Ecol. Prog. Ser., 52: 7-16.

ter Braak, C.J.F. - 1987. Ordination. Chapter 5. In: R.H.G. Jongman, C.J.F. ter Braak, O.F.R. van Tongeren (Eds.), Data analysis in community and landscape ecology, pp. 91-173. PUDOC, Wageningen

ter Braak, C.J.F. - 1988. CANOCO a FORTRAN Program for Canonical Community Ordination by partial, detrended, canonical, correspondence analysis, principal components analysis and redundancy analysis. Version 2.1 Technical report: LWA88-02.

ter Braak, C.J.F. - 1990. Update notes: CANOCO version 3.10.
Copyright Agricultural Mathematics Group, Wageningen.

Uye, S.I. and A. Fleminger. - 1976. Effects of various environmental factors on egg development of several species of Acartia in Southern California. Mar. Biol., 38: 252-262.

Viñas, M.D. and R. Gaudy, R. - 1996. Annual cycle of Euterpina acutifrons (Copepoda: Harpacticoida) in the Gulf of San Matías (Argentina) and in the Gulf of Marseille (France). Sci. Mar., 60(2-3): 307-318

Washington, H.G. - 1984. Diversity, biotic and similarity indices: a review with special relevance to aquatic ecosystem. Water Research 18: 653-694.

Wolda, H. - 1981. Similarity indices, sample size and diversity. Oecologia 50: 296-302.

Scient. ed.: M. Alcaraz 